\title{
Posterior transformation, neurological abnormalities, and severe hematopoietic defects in mice with a targeted deletion of the bmi-1 proto-oncogene
}

\author{
Nathalie M.T. van der Lugt, ${ }^{1}$ Jos Domen, ${ }^{1,2}$ Koert Linders, ${ }^{1}$ Marian van Roon, ${ }^{1}$ Els Robanus-Maandag, \\ Hein te Riele, ${ }^{1}$ Martin van der Valk, ${ }^{1}$ Jacqueline Deschamps, ${ }^{3}$ Michael Sofroniew, ${ }^{4}$ \\ Maarten van Lohuizen, ${ }^{1,5}$ and Anton Berns ${ }^{1,4}$ \\ ${ }^{1}$ Department of Molecular Genetics, The Netherlands Cancer Institute, 1066 CX Amsterdam, The Netherlands; \\ ${ }^{2}$ Department of Pathology, Beckman Center B263, Stanford University, Stanford, California 94305-5428 USA; ${ }^{3}$ Hubrecht \\ Laboratory, 3584 CT Utrecht, The Netherlands; ${ }^{4}$ Somatix Therapy Corporation, Alameda, California 94501 USA; \\ ${ }^{5}$ University of California at San Francisco School of Medicine, Department of Biochemistry and Biophysics, San Fransisco, \\ California 94143-0448 USA
}

The bmi-1 proto-oncogene has been implicated in B-cell lymphomagenesis in E $\mu$-myc transgenic mice. Distinct domains of the Bmi-1 protein are highly conserved within the Drosophila protein Posterior Sex Combs, a member of the Polycomb group involved in maintaining stable repression of homeotic genes during development. We have inactivated the bmi-1 gene in the germ line of mice by homologous recombination in ES cells. Null mutant mice display three phenotypic alterations: (1) a progressive decrease in the number of hematopoietic cells and an impaired proliferative response of these cells to mitogens; (2) neurological abnormalities manifested by an ataxic gait and sporadic seizures; and (3) posterior transformation, in most cases along the complete anteroposterior axis of the skeleton. The observations indicate that Bmi-1 plays an important role in morphogenesis during embryonic development and in hematopoiesis throughout pre- and postnatal life. Furthermore, these data provide the first evidence of functional conservation of a mammalian Polycomb group homolog.

[Key Words: Targeted disruption; bmi-1; posterior transformation; hematopoiesis; IL-7; cerebellum]

Received December 2, 1993; revised version accepted February 3, 1994.

The bmi-1 gene was identified as a common proviral integration site in Moloney murine leukemia virus (Mo$\mathrm{MuLV}$ )-induced B-cell lymphomas in $\mathrm{E} \mu$-myc transgenic mice (Haupt et al. 1991; van Lohuizen et al. 1991a). In $35 \%$ of these B-cell lymphomas, proviral insertions are found in close proximity of the bmi-1 gene, resulting in enhanced transcription of $b m i-1$. In most tissues, low levels of the bmi-1 mRNA are detected, whereas higher mRNA levels are found in thymus, heart, brain, and testes. bmi-1 is also expressed in embryonic stem (ES) cells during embryonic development and in placenta. The bmi-1 gene encodes a nuclear protein of 324 amino acids that harbors several motifs found in transcriptional regulators, including an unusual zinc finger motif shared by several diverse nuclear proteins (van Lohuizen et al. 1991a).

A close relative is mel-18, a gene cloned from a melanoma cell line (Tagawa et al. 1990; Goebl 1991). The mouse Bmi-1 protein has $70 \%$ identity with the Mel-18 protein. mel-18 mRNA is detected in brain, testes, lung, and kidney (M. Alkema, pers. comm.).
Bmi-1-specific motifs are conserved in the Posterior Sex Combs (Psc) protein from Drosophila melanogaster (Jürgens et al. 1985; Adler et al. 1991; Brunk et al. 1991). The conserved domains between Bmi-1 and Psc are located in the amino-terminal part of the much larger Psc protein and are also found in the Suppressor-2 of Zeste [Su(z)2] protein from Drosophila (Adler et al. 1989; Wu et al. 1989; Brunk et al.1991; van Lohuizen et al. 1991b). Drosophila loss-of-function mutants of PSC are embryonic lethals displaying head defects and partial transformation of several segments into more posterior ones, as well as partial ventral-to-dorsal transformations (Jürgens et al. 1985; Adler et al. 1989, 1991). Psc belongs to the Polycomb group $(P C-G)$, the members of which are involved in maintaining homeotic genes in the suppressed state after their local down-regulation at a specific time during development (Lewis 1978; Paro 1990; Zink et al. 1991). These data suggest that Bmi-1 could be involved in the regulation of expression of murine homeotic genes.

To gain more insight into the function of Bmi-1, we 
van der Lugt et al.

have inactivated the bmi-1 gene in mice by homologous recombination in ES cells. Here, we report on the phenotypic alterations seen in hematopoietic organs, the nervous system, and the axial skeleton of bmi-1 - /mice.

\section{Results}

\section{Generation of bmi-1 null mutant mice}

To inactivate the bmi-1 gene in ES cells, two replacement-type targeting constructs were made (Fig. 1B). The deletion of the majority of the coding region, including the AUG start codon, the zinc finger motif, and part of the helix-turn-helix motif, is expected to result in a genuine null mutant of the gene. Upon electroporation of the targeting constructs into ES cells, hygromycin- and G418-resistant clones were expanded and screened for homologous recombination events by Southern blot hybridization (by use of probe B; see Fig. 1A). As shown in Figure $2 \mathrm{a}$, successfully targeted ES cell clones were obtained with both the Hyg and Neo construct. In $14 \%$ of the clones analyzed, the $8.5-\mathrm{kb}$ wild-type HindIII fragment was replaced by either a $8.2-$ or a $7.5-\mathrm{kb}$ HindIIIKpnI fragment, respectively. Two $\mathrm{Hyg}^{\mathrm{R}}$-and two G418 ${ }^{\mathrm{R}}$. targeted ES cell clones were used to generate chimeric mice. Chimeras transmitting the targeted $b m i-1$ allele to their offspring were obtained with each ES cell clone injected into $\mathrm{C} 57 \mathrm{Bl} / 6$ blastocysts. Chimeric males were crossed with either 129/Ola or FVB female mice to generate inbred or outbred offspring, respectively. Heterozygous bmi-1 mutant mice were obtained at the expected frequency (121 of 256 pups born) and appeared healthy and fertile. Crossbreeding of heterozygous bmi-1 mutant mice resulted in birth of mice homozygous for the $b m i-1$ mutant allele (bmi-1 - / -) (Fig. 2b). Rehybridization of the blot shown in Figure $2 b$ with a probe located in the region that was deleted from the targeting construct proved that this coding region was absent in the bmi-1 $-/$ - genome (Fig. 2c). Northern analysis with a $b m i-1$ cDNA probe (comprising exons 2-9) revealed no bmi-1 transcripts present in spleen, testis, liver, and brain of bmi-1 - / - mice and no Bmi-1 protein could be detected by Western blot analysis of nuclear extracts of brain and

(A)

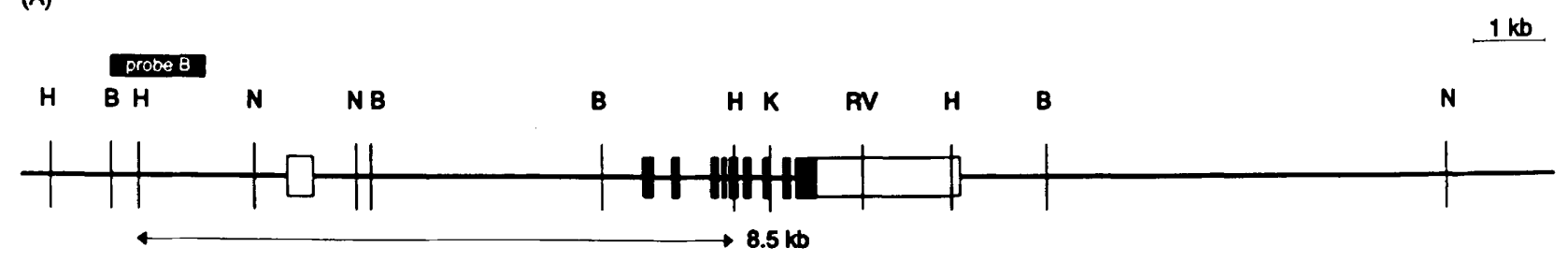

(B)
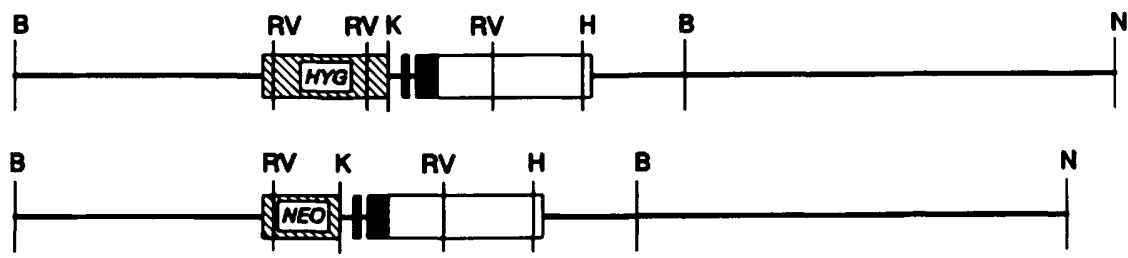

(C)
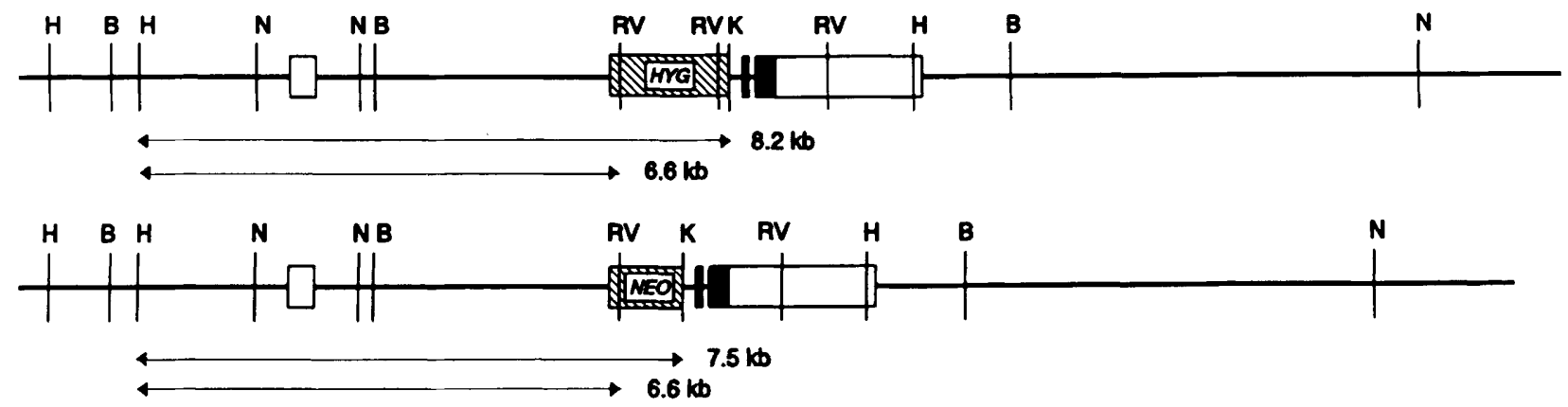

Figure 1. Structure of the bmi-1 targeting constructs. $(A)$ Genomic organization of the bmi-1 locus on mouse chromosome 2. (B) Structure of the two targeting constructs. (Top) Hygromycin construct, containing PGK-Hyg in the opposite transcriptional orientation to the bmi-1 gene. (Bottom) Neomycin construct, containing the PMCl-Neo marker in the same transcriptional orientation as the $b m i-1$ gene. $(C)$ Structure of the $b m i-1$ locus resulting from homologous recombination between the endogenous locus $(A)$ and either the Hyg construct (top) or the Neo construct (bottom). (Solid rectangles) Protein-coding exons; (open rectangles) nontranslated exon segments. Restriction sites used for cloning and screening are shown [(H) HindIII; (B) BamHI; (N) NotI; (RV) EcoRV; (K) KpnI]. The double-headed arrows indicate the expected fragment length upon digestion with HindIII and KpnI (top arrow) or HindIII and EcoRV (bottom arrow) and hybridization with probe B (1.5-kb SacI fragment). 
a

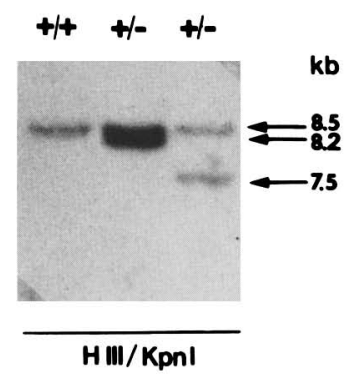

b

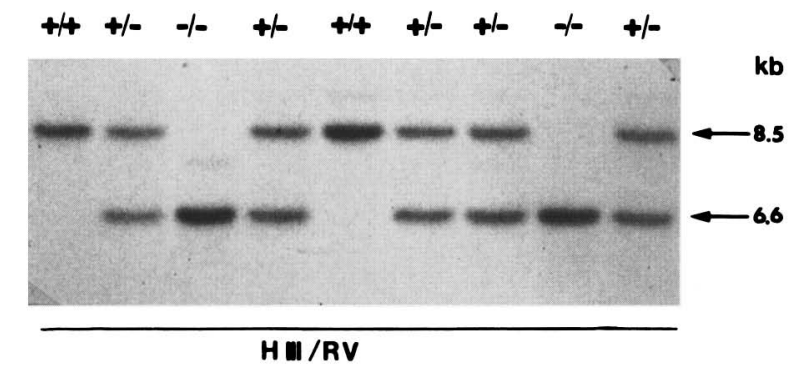

C

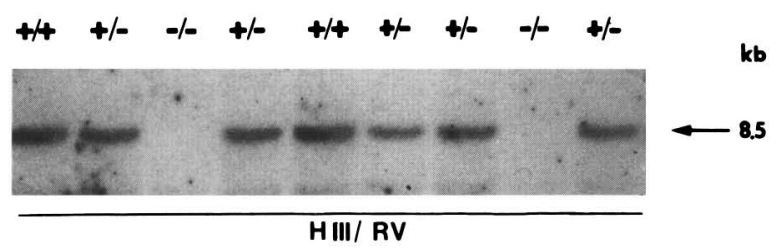

Figure 2. Southern blot analysis of the ES cell clones and the mutant mice. (a) An example of a nontargeted, a Hyg-targeted, and a Neo-targeted ES cell clone, digested with HindIII and KpnI and hybridized with probe B. (Right) The length (in kilobases) of the hybridizing fragments corresponding to the double-headed arrows in Fig. 1. (b) Genotype of a litter from a intercross of heterozygous bmi-1 mutant mice. Tail DNA was digested with HindIII and EcoRV, and Southern blot analysis was performed with probe B. Of 10 mice, 2 were homozygous for the targeted bmi- 1 allele. The genotypes are indicated above the lanes: $1+1$ $+\mid$ Wild-type $;(+/-\mid$ heterozygote; $1-/-1$ homozygote. (c) The blot shown in $b$ was washed and rehybridized with a probe from within the deletion (2.5-kb BamHI-KpnI fragment). In bmi-1 $-/$ - mice, no fragment hybridizing to this probe was detected. testis (not shown). Northern analysis did not reveal changes in the expression level of the mel-18 and bup (bmi-1 upstream protein; Haupt et al. 1992) genes in brain, liver, testis, and spleen (not shown), showing that disruption of the $b m i-1$ gene does not affect the expression of these genes.

\section{Viability of bmi-1 - / - mice}

From heterozygote crosses, $25 \%$ of the mice observed at birth were of the bmi-1 $-/$ - genotype (Table 1). This was the case in both inbred and outbred crosses of heterozygotes derived from each ES cell clone used to generate chimeric mice. However, when animals were genotyped after weaning ( 3 weeks of age), bmi-1 - / - mice were found at a lower frequency, in both inbred and outbred crosses (Table 1). This is mainly caused by death of bmi-1 - / - mice shortly after birth (day 1-3). These mice are selectively cannibalized by their mothers, suggesting that they have reduced fitness or show aberrant behavior.

bmi-1 - / - mice that do survive the first few days after birth $( \pm 50 \%)$, are significantly smaller than their control littermates, which becomes apparent in the first 2 weeks after birth. With increasing age, Bmi-1-deficient mice display waves of sickness that finally result in death at an age varying from 3 to 20 weeks. Histological analysis of moribund mice often reveals pneumonia, anemia, and opportunistic infections of the intestinal tract. Importantly, for these analyses and all described below, mice obtained from at least two different targeted ES cell clones were used, and no differences in phenotype were observed.

\section{Neurological abnormalities in bmi-1 - / - mice}

At the age of 2-4 weeks, Bmi-1-deficient mice start displaying an ataxic gait. They walk uncoordinated and fall over onto their side frequently. To measure the severity of this ataxia, bmi-1 - / - mice were submitted to a Rotarod test (Kaplan and Murphy 1972, with modifications according to Gipon 1977), where the mouse is tested for its ability to stay on a rotating rod. Control littermates were able to keep balance for at least $120 \mathrm{sec}$, whereas the bmi-1 $-/-$ mice fell off the rod after $\sim 30$ sec. The ataxia becomes more severe with age and is

Table 1. Offspring of intercrosses of heterozygous bmi-l mutant mice

\begin{tabular}{|c|c|c|c|c|c|c|}
\hline & \multicolumn{3}{|c|}{ Newborn } & \multicolumn{3}{|c|}{ Weaning age } \\
\hline & $\begin{array}{l}\text { wild type } \\
(+1+1\end{array}$ & $\begin{array}{l}\text { heterozygote } \\
\qquad 1+1-1\end{array}$ & $\begin{array}{l}\text { homozygote } \\
\qquad(-1-1)\end{array}$ & $\begin{array}{l}\text { wild type } \\
(+1+1\end{array}$ & $\begin{array}{l}\text { heterozygote } \\
\qquad(+1-1\end{array}$ & $\begin{array}{c}\text { homozygote } \\
(-1-1\end{array}$ \\
\hline Total & $\begin{array}{l}44 \\
(23 \%)\end{array}$ & $\begin{array}{l}100 \\
(52 \%)\end{array}$ & $\begin{array}{l}49 \\
(25 \%)\end{array}$ & $\begin{array}{l}99 \\
(30 \%)\end{array}$ & $\begin{array}{l}187 \\
(57 \%)\end{array}$ & $\begin{array}{l}44 \\
|13 \%|\end{array}$ \\
\hline Inbred & $\begin{array}{c}8 \\
(19 \%)\end{array}$ & $\begin{array}{c}24 \\
(57 \%)\end{array}$ & $\begin{array}{l}10 \\
(24 \%)\end{array}$ & $\begin{array}{l}13 \\
(25 \%)\end{array}$ & $\begin{array}{l}36 \\
(69 \%)\end{array}$ & $\begin{array}{l}3 \\
(6 \%)\end{array}$ \\
\hline Outbred & $\begin{array}{l}36 \\
(24 \%)\end{array}$ & $\begin{array}{l}76 \\
(50 \%)\end{array}$ & $\begin{array}{l}39 \\
(26 \%)\end{array}$ & $\begin{array}{l}86 \\
(31 \%)\end{array}$ & $\begin{array}{l}151 \\
(54 \%)\end{array}$ & $\begin{array}{l}41 \\
(15 \%)\end{array}$ \\
\hline
\end{tabular}


accompanied by sporadic epileptic-like seizures and tremors.

Histological analysis of the cerebral cortex, the spinal cord, and the peripheral nerves of the hindlegs did not reveal clear alterations in the $b m i-1-/-$ mice. The cerebellum however, a major motor coordination center, showed clear abnormalities in Bmi-1-deficient mice. The cell density in the different layers of the cerebellum was significantly decreased in bmi-1 $-/-$ mice compared with control littermates (Fig. 3A). Most pronounced was the reduction in thickness of the molecular layer with massive loss of neurons. In addition, Purkinje cells were markedly shrunken and reduced in number. In the hippocampus of some but not all bmi-1 - / - mice, dark shrunken and degenerating neurons were observed. Immunohistological analysis indicated that major white matter tracts, such as the corpus callosum, showed extensive gliosis in the form of many glial fibrillary acidic protein (GFAP)-positive reactive astrocytes (not shown).

\section{Hematopoietic abnormalities}

Macroscopic examination of 2- to 3-month-old (further referred to as adult) $b m i-1-/-$ mice showed a severely involuted thymus and a significantly smaller spleen size as compared with wild-type or heterozygous littermates. Histological analysis showed severe hypoplasia of the thymic cortex (Fig. $3 \mathrm{C}$ ) and of both the red and white pulp regions of the spleen. However, the morphological changes observed in bone marrow were most profound. In tibiae, femurs, pelvis, and even vertebrae of these mice, regions of hematopoiesis were severely hypoplastic and occupied by adipocytes (Fig. 3B). This was observed both in adult and in 2-week-old bmi-1 - / - mice.

Nucleated cells were quantitated in peripheral blood, in bone marrow obtained from femurs and tibiae, and in cell suspensions of thymus and spleen of mice at different ages. From early on in development the hematopoietic cell counts were reduced in $b m i-1-/-$ mice, and a further progressive decrease was observed: In the adult the cell counts were reduced to $\sim 30 \%$ of wild-type levels, and the number of thymocytes even decreased to $<1 \%$ (Fig. 4). The determination of red blood cell counts and several other blood parameters (hemoglobin concentration, hematocrit, platelet count, and mean red blood cell volume) did not reveal abnormalities in bmi-1 - / mice (not shown).

To determine whether specific cell populations were affected in Bmi-1-deficient mice, flow cytometric analysis (FACS) of thymocytes, splenocytes, and bone marrow cells was performed with standard lymphoid and myeloid markers (Table 2). The immature $\mathrm{CD} 4^{-} / \mathrm{CD} 8^{-}$ thymocyte population is increased from $4 \%$ of total cells in $b m i-1+/+$ mice to $90 \%$ of total cells in bmi-1 - / mice, although in absolute numbers, this population size is decreased to $12 \%$ of wild-type (Table 2). On average, one-third of these immature $\mathrm{CD} 4^{-} / \mathrm{CD} 8^{-}$thymocytes stain positive for the interleukin-2 (IL2) receptor and one-third for heat stable antigen (HSA). The presence in bmi-1 - / - mice of mainly immature thymocytes sug- gests that these cells fail to mature either as a direct result of the absence of Bmi-1 from these cells or by the overall stress imposed on these animals by the absence of Bmi-1.

In bone marrow of bmi-1 $-1-$ mice the absolute numbers of both $\mathrm{B}$ lymphoid $\left(\mathrm{B}^{2} 20^{+}\right)$and myeloid (Mac$1^{+}, \mathrm{Gr}^{+}$) cell populations were significantly reduced to 14 and $\sim 30 \%$ of wild-type levels, respectively (Table 2 ). A more detailed analysis of B-cell populations as defined by Hardy et al. (1991) was performed. The absolute number of immature $\mathrm{B}$ cells $\left(\mathrm{B} 220^{+} / \mathrm{HSA}^{+}\right.$and $\mathrm{B} 220^{+} /$ $\left.\mathrm{BPl}{ }^{+}\right)$, as well as the number of mature B cells $\left(\mathrm{B} 220^{++} /\right.$ $\operatorname{sIg}^{+} \mid$, was significantly reduced in bmi-1 -/ - mice compared with wild-type mice. However, the most immature cell population $\left(\mathrm{B} 220^{+} / \mathrm{S}^{+}\right)$was decreased to a lesser extent, indicating that with increasing maturation, B-cell populations are affected more severely. However, it is important to stress that B cells of all maturation stages that we could identify were found in bmi-1 $-1-$ mice.

FACS analysis of splenocytes of bmi-1 - / - mice shows that both the B- and T-cell compartments are reduced in size although their relative percentages have not changed dramatically $153-40 \%$ and $30-26 \%$, respectively).

\section{Functional analysis of bone marrow cells}

Bone marrow colony assays were performed to compare growth factor responses of hematopoietic cells of bmi-1 $-/-$ mice and control littermates (Fig. 5a,b). Freshly isolated bone marrow cells were cultured in soft agar in the presence of either interleukin-3 (IL-3), macrophage colony-stimulating-factor (M-CSF), steel factor (SF), interleukin-7 (IL-7), or lipopolysaccharide (LPS), and at day 8 , the number of colonies was determined. Bone marrow cells of bmi-1 - / - mice did not respond to IL-7, which normally induces pre-B-cell colonies (Lee et al. 1989; Suda et al. 1989). The response to IL-7 + SF, which also induces more primitive cells to differentiate into pre-B cells (McNiece et al. 1991), was changed: In the absence of Bmi-1, few colonies were present, and these consisted predominantly of neutrophils. This was also seen with wild-type bone marrow in response to SF only. Furthermore, no colonies were obtained in response to LPS, indicating that functional mature B cells were virtually absent from bmi-1 - / - bone marrow. The number of myeloid (macrophage) colonies induced by L-cell-conditioned medium, containing M-CSF (Stanley et al. 1983), was reduced 4- to 10 -fold in bmi-1 - / - mice as compared with wild type. The number of IL-3-responsive colonies was not reduced significantly in $b m i-1-/-$ mice.

An impaired response to IL-7 and M-CSF $\{P=0.03$ and $P=0.05$, respectively) was also observed in colony assays of fetal liver cells [ 14.5 days postcoitum $(\mathrm{dpc})]$, whereas the response to IL-3 was normal (Fig. 5c). This shows that defects in hematopoiesis in bmi-1 $-/-$ mice start early in development and are not a consequence of overall growth retardation of the animals.

Interestingly, also the numbers of IL-7-, LPS- and 


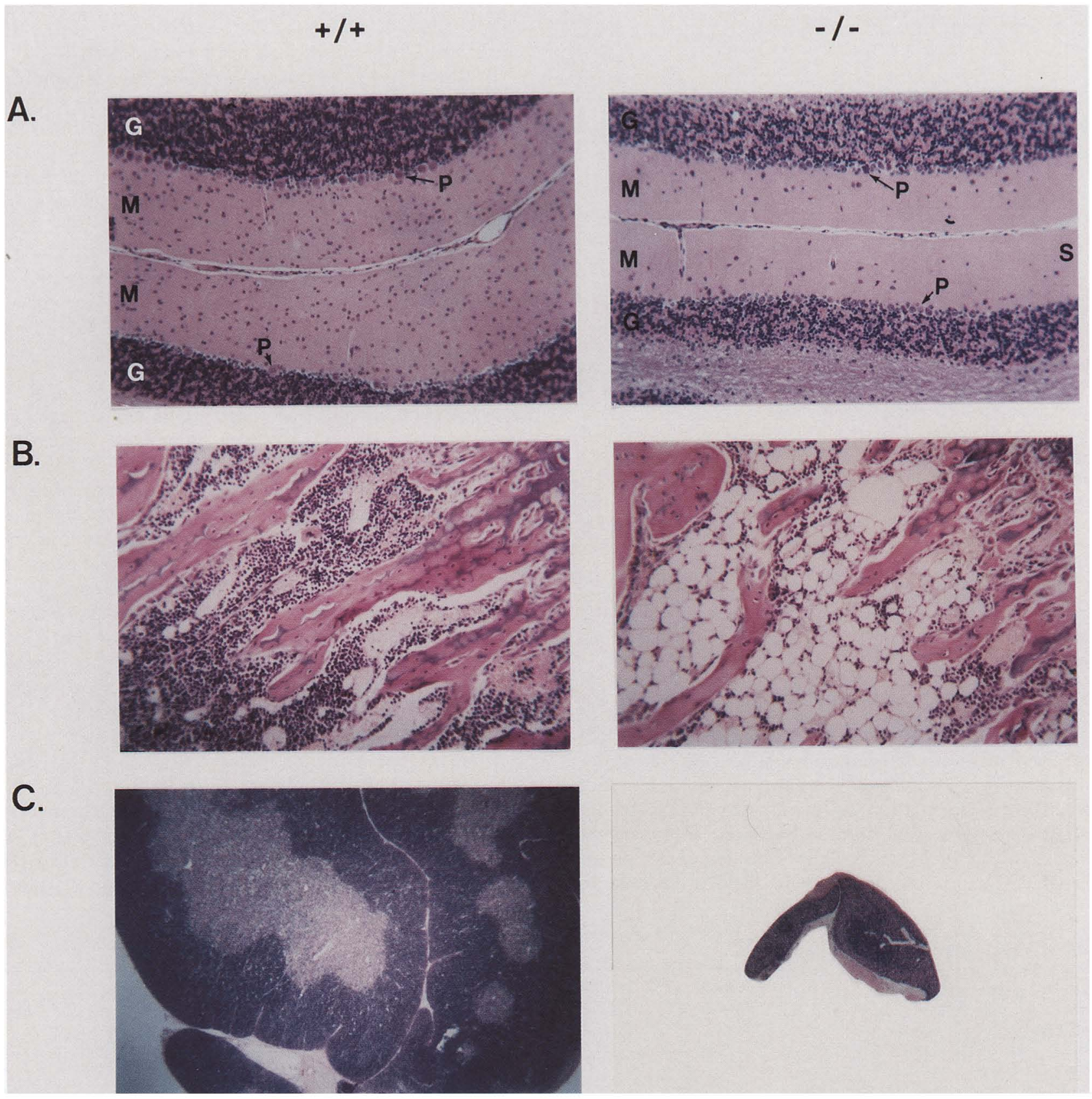

Figure 3. Histological analysis of tissues from adult bmi-1 $+/+$ and $-/-$ mice. HE-stained cross sections through the cerebellum $(A)$, bone marrow hematopoietic regions of the femur $(B)$, and the thymus $(C)$ of a bmi-1-l- mouse and a control littermate. $(A)$ Cerebellum comprising the granular layer $(G)$, Purkinje cells (P), and the molecular layer (M). Disregard S. Cell densities are clearly reduced in bmi-1 - / - mice. $(B)$ Note that hematopoieisis is severely reduced and that large numbers of adipocyte cells are observed in $b m i-1-1-$ mice. $(C)$ In bmi-1 - / - mice the thymic size is reduced and the thymic cortex has completely dissappeared. Representative examples of analysis done on 5-10 inbred or outbred bmi-1 - / mice are shown. Magnification $(A$ and $B), 8 \times ; C, 2 \times$.

M-CSF-responsive bone marrow colonies found with bmi-1 $+/-$ cells were significantly reduced compared with bmi-1 $+1+$ cells (Fig. 5). This gene dosage effect was not reflected in a reduced health, fertility, hematopoietic cell count, or histological abnormalities.

To confirm the absence of IL-7-responsive cells from the bone marrow of bmi-1 $-/-$ mice, larger numbers of cells were tested in liquid bone marrow cultures. Bone marrow cells from adult $b m i-1-1-$ mice did not grow upon exposure to IL-7 with or without SF, whereas bone marrow cultures of wild-type mice gave normal levels of proliferating cells (data not shown). Preliminary data showed the same results with bone marrow cells obtained from 2-week-old bmi-1 - / - mice. 
van der Lugt et al.

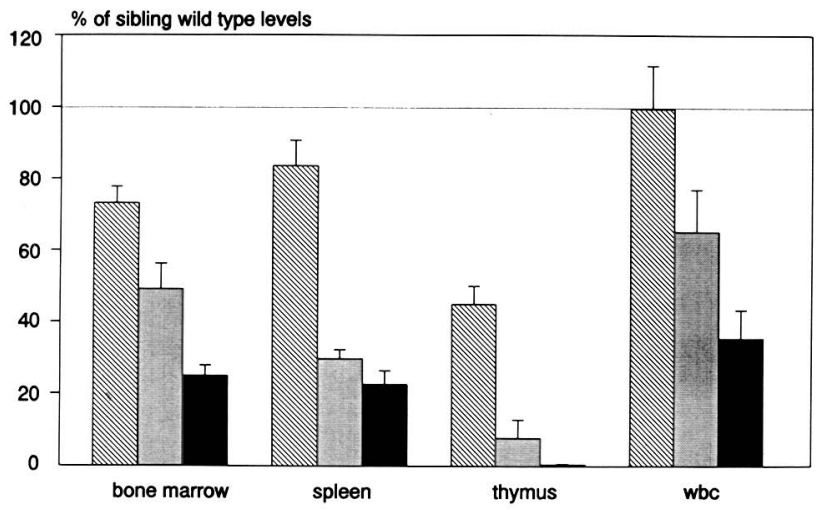

Figure 4. Nucleated cell numbers of hematopoietic organs are reduced in bmi-1 $-1-$ mice. The number of nucleated cells in bone marrow (two femurs), spleen, thymus, and blood (wbc) was determined in newborn (hatched bar), 2-week-old (shaded bar), and adult (solid bar) Bmi-1-deficient mice, and displayed as a percentage of the wild-type numbers, which were set to $100 \%$. Instead of newborn bone marrow counts, fetal liver counts ( 14.5 $\mathrm{dpc}$ ) were determined. Even if the reduced body size/weight of the bmi-1 $-/-$ mice (on average twofold in adults) is taken into consideration, hematopoietic cell counts are significantly and progressively reduced in all the hematopoietic organs of bmi-1 -/- mice. Number of mice analyzed: adult, 8-10; 2-week-old, 2-4; fetal, 3-5.

\section{Proliferative responses of mature $B$ and $T$ cells}

The response of splenocytes to the B-cell mitogen LPS or the T-cell mitogen concanavalin A (ConA) was determined by a $\left[{ }^{3} \mathrm{H}\right]$ thymidine incorporation assay (not shown). LPS stimulation of splenocytes from newborn bmi-1 $-1-$ mice was normal, but from adults it was reduced 8- to 10-fold when compared with wild-type littermates. The same reduction was seen in response to
ConA. These data suggest that the splenocytes present in adult bmi-1 $-1-$ mice may not be functional.

To further assess peripheral B-cell function, serum immunoglobulin levels of $11 \mathrm{bmi-1}-/-$ mice were compared with those of $12 \mathrm{bmi}-1+/+$ mice. The serum IgM levels appeared to be reduced to $70 \%$ of wild-type levels, whereas the serum IgG levels were slightly increased (not shown). However, the number of white blood cells in adult $b m i-1-/-$ mice was, on average, $35 \%$ of wild type (Fig. 4), suggesting that the remaining B cells compensate by the production of relatively large amounts of immunoglobulins.

Posterior transformation in the skeleton of bmi-1 - /mice

The Psc gene, like all Polycomb group genes that have been analyzed so far, showed a ubiquitous expression pattern during development in Drosophila (Martin and Adler 1993). A comparable expression pattern was detected for the bmi-1 gene during mouse development. Northern analysis of RNA isolated from embryos at different stages of development revealed expression of bmi-1 at least from $10.5 \mathrm{dpc}$ on (M. Alkema, pers. comm.). In situ RNA hybridization on sections of wildtype embryos (12.5 and $14.5 \mathrm{dpc}$ ), showed low bmi-1 expression levels in virtually all tissues and higher expression levels in brain, spinal cord, kidney, lung, and gonads anlage, whereas no bmi-1 mRNA was detected in bmi-1 $-1-$ embryos (not shown).

The conserved domains between Bmi-1 and Psc combined with the comparable expression patterns suggest a possible role for Bmi-1 in repression of murine homeotic genes. Therefore, we screened the axial skeleton of bmi-1 $-/-$ mice for the presence of morphological transformations, such as those observed in hox mutant

Table 2. Flow cytometric analysis

\begin{tabular}{|c|c|c|c|c|c|}
\hline Cell type & Marker & $\begin{array}{l}\text { Percent } \\
\text { wild type } \\
(+1+1\end{array}$ & $\begin{array}{l}\text { Percent } \\
\text { heterozygote } \\
(+1-1\end{array}$ & $\begin{array}{l}\text { Percent } \\
\text { homozygote } \\
(-1-1\end{array}$ & $\begin{array}{l}\text { Percent of wild type } \\
\text { (absolute number) }\end{array}$ \\
\hline \multirow[t]{7}{*}{ Bone marrow } & $\mathrm{B} 220^{+}$ & $26 \pm 4|n=9|$ & $27 \pm 5(n=4)$ & $13 \pm 4(n=9)$ & $14 \pm 8(n=9)$ \\
\hline & $\mathrm{B} 220^{+} \mathrm{S}^{+}$ & $4 \pm 1(n=4)$ & $3 \pm 1(n=2)$ & $3 \pm 1(n=4)$ & $25 \pm 7(n=4)$ \\
\hline & $\mathrm{B}_{220^{+}} \mathrm{HSA}^{+}$ & $15 \pm 1(n=2)$ & & $10 \pm 2(n=2)$ & $14 \pm 3(n=2)$ \\
\hline & $\mathrm{B} 220^{++} \mathrm{BP}^{+}$ & $9 \pm 2(n=2)$ & & $4 \pm 1(n=2)$ & $9 \pm 1(n=2)$ \\
\hline & $\mathrm{B} 220^{++} \mathrm{sIg}^{+}$ & $9 \pm 1(n=6)$ & $9(n=1)$ & $3 \pm 1(n=5)$ & $7 \pm 1(n=5)$ \\
\hline & $\mathrm{Gr}^{+}$ & $37 \pm 2(n=6)$ & $23 \pm 3(n=2)$ & $39 \pm 8(n=6)$ & $31 \pm 4(n=6)$ \\
\hline & $\mathrm{Mac}-1^{+}$ & $40 \pm 3(n=5)$ & $25 \pm 10(n=2)$ & $45 \pm 8(n=5)$ & $36 \pm 5(n=5)$ \\
\hline \multirow[t]{2}{*}{ Splenocytes } & $\mathrm{B} 220^{+}$ & $53 \pm 4(n=6)$ & $54 \pm 1(n=2)$ & $40 \pm 5(n=6)$ & $17 \pm 3(n=6)$ \\
\hline & $\mathrm{TCR} \alpha \beta^{+}$ & $30 \pm 3(n=7)$ & $32 \pm 5(n=2)$ & $26 \pm 3(n=7)$ & $24 \pm 7(n=7)$ \\
\hline \multirow[t]{8}{*}{ Thymocytes } & $\mathrm{CD}^{-}{ }^{-} 8^{-}$ & $4 \pm 2(n=7)$ & $4 \pm 1(n=2)$ & $90 \pm 4(n=8)$ & $12 \pm 7(n=8)$ \\
\hline & $\mathrm{CD}_{4}^{+} 8^{+}$ & $83 \pm 7(n=7)$ & $84 \pm 2(n=2)$ & $5 \pm 3(n=8)$ & $0.03 \pm 0.01(n=8)$ \\
\hline & $\mathrm{CD} 4^{+} 8^{-}$ & $9 \pm 4(n=7)$ & $7 \pm 1(n=2)$ & $2 \pm 2(n=8)$ & $0.14 \pm 0.1(n=8)$ \\
\hline & $\mathrm{CD}^{-} 8^{+}$ & $4 \pm 3(n=7)$ & $6 \pm 1(n=2)$ & $3 \pm 2(n=8)$ & $0.4 \pm 0.3(n=8)$ \\
\hline & $\mathrm{IL}-\mathrm{R}^{+}$ & $2 \pm 0.2(n=3)$ & $2 \pm 0.1(n=2)$ & $39 \pm 25(n=3)$ & $14 \pm 8(n=3)$ \\
\hline & $\mathrm{HSA}^{+}$ & $2 \pm 0.4(n=3)$ & $2 \pm 0.2(n=2)$ & $36 \pm 37(n=3)$ & $15 \pm 15(n=3)$ \\
\hline & $\mathrm{CD}^{+}+$ & $15 \pm 2\{n=3\}$ & & $11 \pm 2\{n=3\}$ & $0.2 \pm 0.1(n=3)$ \\
\hline & $\operatorname{TCR} \alpha \beta^{+}$ & $20 \pm 13(n=3)$ & $23 \pm 1(n=2)$ & $6 \pm 3(n=3)$ & $0.14 \pm 0.1(n=3)$ \\
\hline
\end{tabular}

Percentage \pm S.E.M. of marker $\left.\right|^{+} \mid$cells per cell type.

aPercentage of absolute number of marker $\left(^{+}\right)$cells in adult bmi-1 $-/-$mice compared with bmi-1 $+/+$mice. 

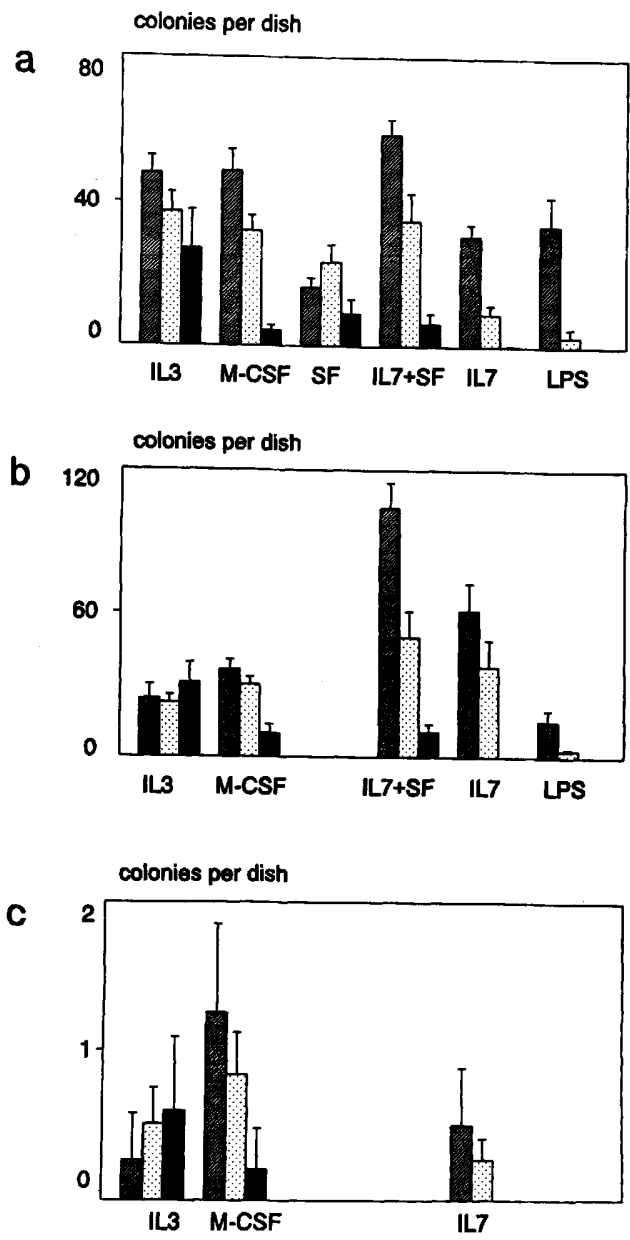

Figure 5. Colony assays on bone marrow of Bmi-1-deficient mice. Femur- and tibia-derived bone marrow cells $(a, b)$ or 14.5 dpc fetal liver cells $\langle c|$ of $b m i-1-/-$ and $+1+$ mice at the adult stage $(a)$ and at 2 weeks of age $\langle b|$ were assayed in soft agar for colony-forming cells, in the presence of the growth factors indicated. The results, mean \pm S.E.M., are given as absolute number of colonies per dish. (Shaded bars) bmi-1 $+1+$; (dotted bars) bmi-1 $+1-$; (solid bars) bmi-1 -/ . (a) Results of 5 bmi-1 $+/+, 1$ bmi-1 $+/-$, and 4 bmi-1 $-/-$ adult mice; $(b)$ results of $3 \mathrm{bmi}-1+/+, 5 \mathrm{bmi}-1+/-$, and $2 \mathrm{bmi}-1-/-2$-week-old mice; $\langle c|$ results of $4 \mathrm{bmi}-1+/+, 15 \mathrm{bmi}-1+/-$, and $5 \mathrm{bmi}-1$ -1 - embryos. The experiments were performed in triplicate with cells isolated from outbred mice.

mice. The analysis of skeletal whole mounts of newborn bmi-1 - / - mice revealed morphological changes at several positions along the anteroposterior axis (Fig. 6; Table 3). These changes included ( 1 ) dorsal, an extra piece of bone rostral to the atlas (first cervical vertebra, C1), where in control mice no vertebra is present; (2) the broadening and splitting of the neural arch of the atlas or the axis (second cervical vertebra, C2); $(3)$ the transformation of the seventh cervical vertebra (C7) to the first thoracic vertebra ( $T 1$ ), evidenced by the presence of ribs at $\mathrm{C7}$, which then fuse on the ventral side with the ribs associated with $\mathrm{T} 1 ;(4)$ the transformation of $\mathrm{T} 7$ to $\mathrm{T} 8$, resulting in the presence of six vertebrosternal ribs instead of seven in control mice $;(5)$ the transformation of
T13 to the first lumbar vertebra (L1), evidenced by the absence or degeneration of the ribs normally associated with T13; and (6) the transformation of L6 to the first sacral vertebra ( $\mathrm{S} 1$ ), evidenced by the association of the ilial bones with L6 in bmi-1 - / - mice instead of S1 in control mice. Altogether, these alterations indicate that the absence of Bmi-1 results in posterior transformation along the anteroposterior axis and implicate a role for Bmi-1 in specifying vertebral identity. Obvious abnormalities of the limbs and the occipital bones of the skull were not observed in the bmi-1 - / - mice.

Table 3 shows that there is no full penetrance of the transformations (although every bmi-1 - / - mouse has at least one of them and $87 \%$ of the bmi-1 $-/-$ mice have multiple transformations) and that most transformations can be found in an asymmetric form (one side). This could correlate to the hybrid genetic background (129/Ola-FVB) of the analyzed mice, because we also observe differences in the penetrance of the phenotype between different litters. A partial penetrance of skeletal abnormalities was also observed for hox mutant mice with a hybrid genetic background (Le Mouellic et al. 1992; Ramírez-Solis et al. 1993). Unfortunately, we could not perform the analysis with bmi-1 - / $129 /$ Ola inbred mice, because of insufficient numbers of mice. As indicated in Table 3, some of the skeletal transformations were also observed in the bmi-1 +/ - mice, again suggesting a gene dosage effect for bmi-1.

\section{Discussion}

Neurological abnormalities in bmi-1 - / - mice

bmi-1 - / - mice showed an ataxic gait and abnormalities in the molecular, Purkinje cell, and granular layers of the cerebellum. A correlation between ataxia and morphological abnormalities in the cerebellar layers has been reported previously for several different mutant mouse strains [nervous, Purkinie cell degeneration, Lurcher, and weaver (for review, see Lyon and Searle 1989|]. In contrast to the bmi-1 - / - mice, however, the molecular layer of the cerebellum is not affected in these mutant mice, nor in other mouse strains with neurological aberrations. Therefore, it is unclear what role the markedly reduced cell density in the molecular layer of the bmi-1 - / - mice plays in the ataxic phenotype.

Dark shrunken cells were observed in the hippocampus of some of the bmi-1 - / - mice. It has been reported that the presence of these cells is compatible with post seizure degeneration (Lothman et al. 1991). However, it is as yet unclear what causes the seizures in the bmi-1 $-/-$ mice. The basis of the extensive white matter gliosis in the form of many GFAP-positive astrocytes remains to be investigated.

Hematopoietic defects in fetal liver and bone marrow of bmi-1 - / - mice

In spite of the fact that hematopoietic cells from the fetal liver of bmi-1 $-1-$ mice show major growth defects in 
van der Lugt et al.

A

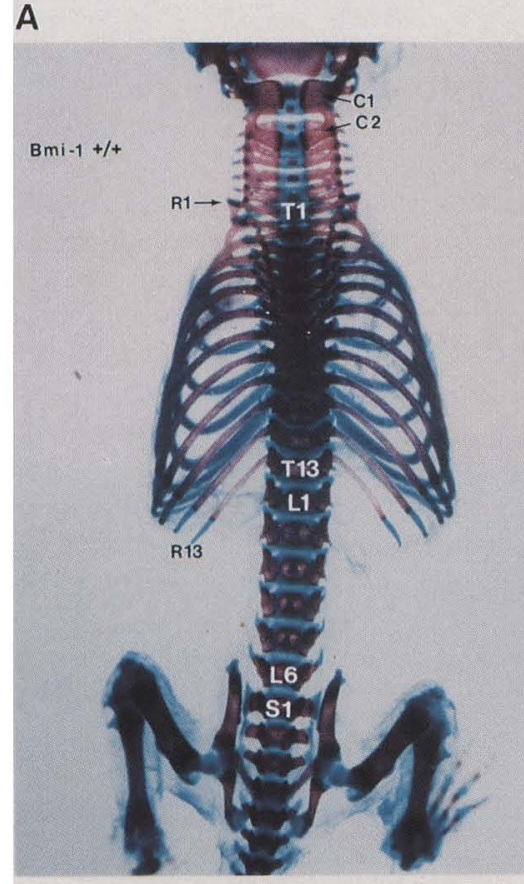

D

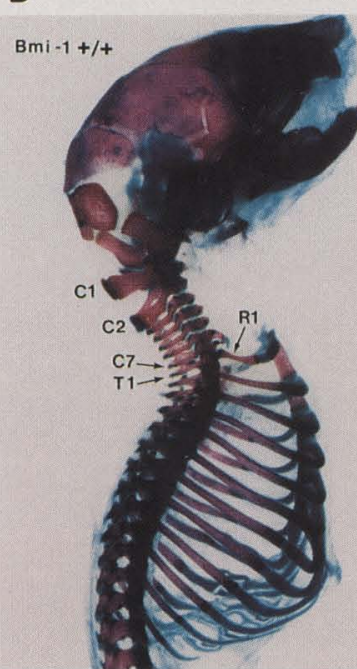

E
B

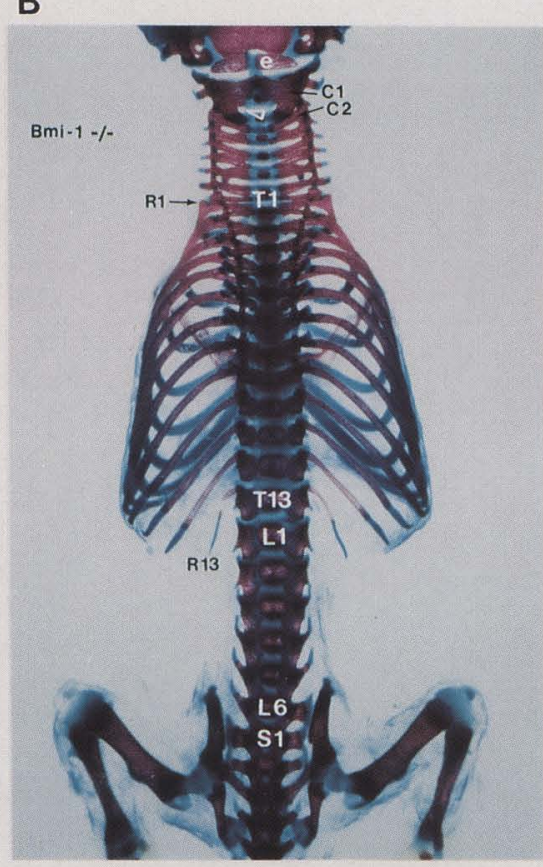

C

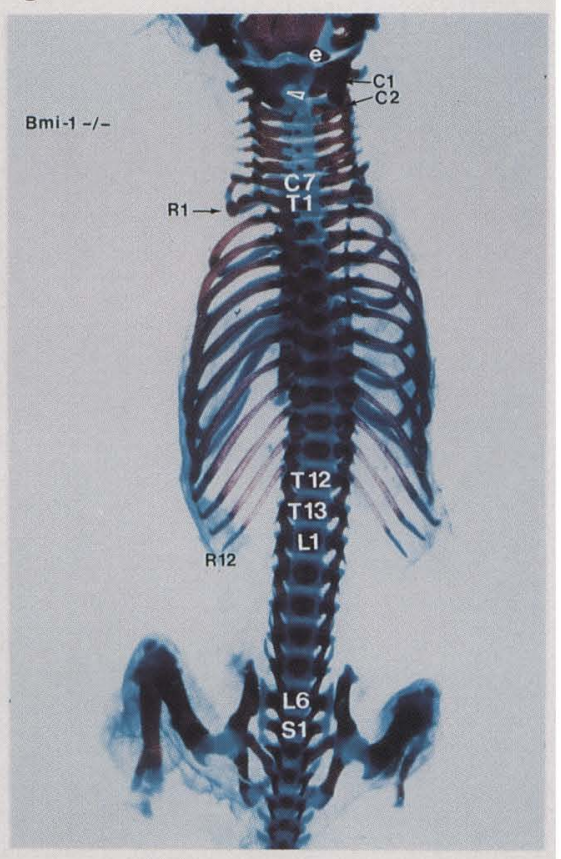
Bmi-1 -/-

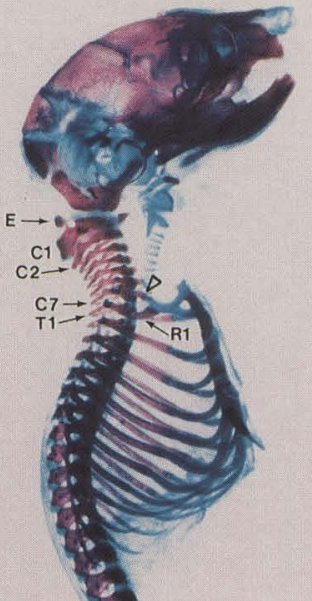

F

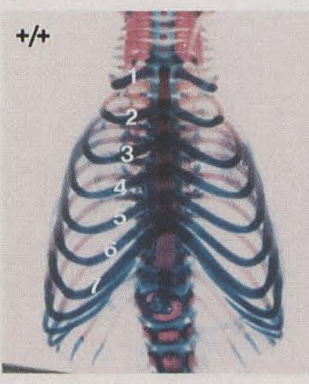

G

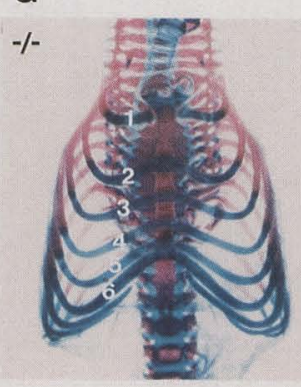

Figure 6. Axial skeleton analyses of $b m i-1-l-$ and $+/+$ mice. Shown are the skeleton analyses from newborn mice obtained from Hyg-targeted clone 62. A similar phenotype was present in mice from Neo-targeted clone $44 .(A-C)$ Dorsal view of wild-type $(A)$ and bmi-1 $-/-(B, C)$ skeletons. (e) An extra piece of bone rostral to the atlas $(C 1)$, on both sides in $B$, on one side in $C$, and absent in wild-type $(A)$. The open arrowhead in $B$ and $C$ points to the broadened and split atlas $(C 1)$. The thirteenth thoracic vertebra (T13) is associated with degenerated ribs $(\mathrm{R} 13)$ in $B$ and with no ribs in $C$, indicating transformation of T13 to the first lumbar vertebra (L1). The sixth lumbar vertebra (L6) in $B$ is on one side (right) transformed to the first sacral vertebra (S1) but is completely transformed to $\mathrm{S} 1$ in $C$. Note the difference in penetrance of the transformations between the two bmi-1- $1-$ mice $(B, C)$. $(D, E)$ Lateral view of the occipital, cervical, and thoracic region of wild-type $(D)$ and $b m i-1-/-|E\rangle$ skeletons. (E) The extra piece of bone rostral to the atlas $(\mathrm{Cl})$ (see also e in $B$ and $C$ ). In $E$ the seventh cervical vertebra $(\mathrm{C} 7)$ is associated with a vertebrosternal rib (open arrowhead), which fuses with the rib (Rl) associated with the first thoracic vertebra (T1). This rib associated with $C 7$ can also be seen in $C$. $(F, G)$ Ventral view of the thoracic region of wild-type $(F)$ and $b m i-1-/-(G)$ skeletons. In the wild-type skeleton $(F)$ seven vertebrosternal ribs are indicated, separated by six sternebrae. In the $b m i-1-/-$ skeleton $(G)$ six vertebrosternal ribs are detected, separated by five sternebrae. The morphology of the first sternebra has changed notably, compared with $F$.

colony assays in vitro, these cells appear to undergo almost normal expansion and maturation in vivo during fetal development. Only later do severe effects become apparent, indicating the progressive character of the hematopoietic defect. We hypothesize that during embryonic development parallel pathways can compensate for 
Table 3. Skeletal abnormalities in bmi-1 $-/-$ mice

\begin{tabular}{|c|c|c|c|c|}
\hline & & \multicolumn{3}{|c|}{$\begin{array}{l}\text { Penetrance of skeletal abnormalities } \\
\qquad(\%)\end{array}$} \\
\hline & & $\begin{array}{c}b m i-1+/+ \\
(n=11)\end{array}$ & $\begin{array}{c}b m i-1+/- \\
(n=26)\end{array}$ & $\begin{array}{c}b m i-1-1- \\
(n=15)\end{array}$ \\
\hline \multirow[t]{2}{*}{ Piece of bone rostral to $\mathrm{Cl}$} & one side & 0 & 0 & 20 \\
\hline & both sides & 0 & 0 & 67 \\
\hline \multirow[t]{2}{*}{ Abnormal neural arch of $\mathrm{Cl}$} & one side & 0 & 0 & 7 \\
\hline & both sides & 0 & 0 & 80 \\
\hline \multirow[t]{2}{*}{ Abnormal neural arch of $\mathrm{C} 2$} & one side & 0 & 11 & 7 \\
\hline & both sides & 0 & 8 & 13 \\
\hline $\mathrm{C} 7 \rightarrow \mathrm{T} 1$ & both sides & 0 & 8 & 47 \\
\hline $\mathrm{C} 7$ partially $\rightarrow \mathrm{T} 1$ & both sides & 0 & 0 & 13 \\
\hline \multirow[t]{2}{*}{ T13: rudimentary ribs } & one side & 9 & 0 & 0 \\
\hline & both sides & 0 & 15 & 73 \\
\hline \multirow[t]{2}{*}{6 vertebrosternal ribs } & one side & 0 & 0 & 23 \\
\hline & both sides & 0 & 0 & 62 \\
\hline \multirow[t]{2}{*}{$\mathrm{L} 6 \rightarrow \mathrm{S} 1$} & one side & 9 & 8 & 13 \\
\hline & both sides & 9 & 4 & 60 \\
\hline
\end{tabular}

the absence of Bmi-1 but that later, proper hematopoietic development becomes more dependent on the pathways affected by $b m i-1$.

The progressively impaired bone marrow hematopoiesis in bmi-1 - / - mice results in decreased cell numbers and replacement of large areas of hematopoiesis in bone by adipocytes. A cell autonomous defect in bmi-1 - / lymphoid and myeloid progenitor cells resulting in reduced hematopoiesis could cause the appearance of adipocytes filling empty spaces. An inverse relationship between the prevalence of adipocytes in bone marrow and hematopoietic activity has been described (Tavassoli et al. 1974|. Alternatively, a progressive degeneration of the microenvironment in bmi-1 $-/-$ mice could contribute to the progressive decline in hematopoiesis. Stromal cells play a pivotal role in maturation of lymphoid and myeloid progenitor cells via cell-cell interactions and cytokine production (for review, see Kincade et al. 1989). Ultimately, long-term bone marrow transplantation assays will have to be performed to prove/exclude defects in bmi-1 - / - bone marrow stromal cells.

In bone marrow colony assays and in liquid culture, Bmi-1-deficient cells do not respond to IL-7. This is not due to the absence of potentially IL-7-responsive pro-B cells as our FACS data show. Stimulation of Bmi-1-deficient bone marrow cells with IL-7 plus SF does not result in the formation of pro-B cell colonies or proliferation in liquid culture, although the SF responsiveness is unaffected (resulting in colonies consisting of neutrophils). These data show that the absence of IL-7 response already resides in early pro-B cells and suggests a potential role for Bmi-1 in the IL-7 signal transduction pathway, by way of which it supports the expansion of committed precursor B cells. This function is in line with its proposed role in lymphomagenesis (M. Alkema, M. van Lohuizen, J. Domen, and A. Berns, in prep.). Furthermore these data show, at least in vitro, a cell autonomous effect of loss of Bmi-1 in B cells.
A recent study (Grabstein et al. 1993) shows the importance of IL-7 during in vivo B-cell differentiation. The treatment of mice with anti-IL-7 monoclonal antibodies completely inhibits the development of B-cell progenitors from the pro-B cell stage onward. However, the data show that bmi-1 - / - progenitor B cells can fully mature to $\mathrm{B} 220^{+} / \mathrm{sIg}^{+} \mathrm{B}$ cells in vivo, although with a reduced efficiency. This suggests that in vivo some segment of the IL-7 pathway is still functional and that, if Bmi-1 acts in this pathway, its function can at least partially be rescued. Given the high degree of homology between Bmi-1 and Mel-18, the latter would be a good candidate to perform this function.

An interesting observation in these colony assays, as well as in the skeletal analysis, is the gene dosage effect of $b m i-1$. This is not commonly found in mice with a disruption of one of the two functional alleles of a particular gene. It is suggestive of Bmi-1 being part of a larger complex in which the stoichiometry of the constituent proteins is critical for the proper functioning of the complex.

Not only lymphopoiesis is affected in the bmi-1 -/ mice, but also myelopoiesis. In contrast to this, erythropoiesis is not affected by the absence of Bmi-1, indicating that Bmi-1 exerts its effect only on specific lineages within the hematopoietic system [possibly a common B-lymphoid/myeloid precursor cell /Cumano et al. 1992)], and probably does not critically affect the hematopoietic stem cells.

\section{Lymphoid defects in the thymus and spleen of} bmi-1-/- mice

The progressively disturbed hematopoiesis in the bone marrow might relate to the appearance of the thymic phenotype in bmi-1 - / - mice later on. Although initially the thymus appears normal, in adult bmi-1 -/ mice it becomes progressively depleted of double-posi- 
tive $\left(\mathrm{CD} 4^{+} / \mathrm{CD} 8^{+}\right)$thymocytes, whereas immature cells $\left(\mathrm{CD}^{-} / \mathrm{CD}^{-}\right)$are still present. Mice lacking c-fos show a comparable phenotype (Wang et al. 1992); although bone marrow hematopoiesis is impaired from early on, thymic involution is observed upon further development.

Thymic involution is also observed in some mutant mice displaying a neurological phenotype, such as Tumbler and Lethargic (Ih) mice (Lyon and Searle 1989). The thymic involution in these mice often coincides with the onset of their neurological symptoms (Dung 1975), a correlation that seems to hold for the bmi-1 - / - mice as well. $1 \mathrm{~h}$ mice show an ataxic gait, sporadic seizures, and thymic involution at 3-4 weeks accompanied by a decrease in the lymphocyte count (Dung 1981). The mapping of the $1 h$ locus on chromosome 2 and the resemblance in phenotype made us perform a more detailed analysis of the $l h$ mice as well. We could not detect differences in the bmi-1 expression pattern by Northern analysis and detected a normal sized Bmi-l protein in these mice. Preliminary analysis do not reveal B-lymphoid aberrations, and no clear morphological changes were observed in the bone marrow, cerebellum, and skeleton of $1 \mathrm{~h}$ mice (not shown). Therefore it is very unlikely that the bmi-1 gene is affected in $1 \mathrm{~h}$ mice, but it is possible that $l h$ and $b m i-1-/-$ mice show a partial overlap with respect to their defective molecular pathways.

The thymic phenotype in bmi-1 - / - mice could also have been caused by IL-7 unresponsiveness of precursor $T$ cells, because IL-7 has been shown to be an important factor for both B- and T-cell development (Suda and Zlotnik 1991).

Splenocytes in bmi-1 - / - mice show a severely impaired proliferative response to $\mathrm{B}$ - and $\mathrm{T}$-cell mitogens. Whether this represents a cell-autonomous defect in lymphoid cells lacking Bmi-1 or a form of anergy, induced by an abnormal microenvironment during their maturation, will have to await results from bone marrow transplantation experiments. In spite of the impaired response to mitogens, the limited number of peripheral $B$ cells are able to remain close to normal levels of serum immunoglobulins. Similar observations were made in leaky scid mice, which contain only a few clones of immunoglobulin-producing $\mathbf{B}$ cells but can have abnormally high concentrations of serum immunoglobulin (Bosma et al. 1988).

\section{Posterior transformation in the bmi-1 $-/-$ mice}

The analyses of the bmi-1 - / - skeletal preparations revealed a number of morphological alterations. The identity of a given vertebra has changed to that of the juxtaposed posterior vertebra, a feature described as posterior transformation. Several hox gain- and loss-of-function mutant mice show comparable posterior or anterior transformation of the axial skeleton (Kessel et al. 1990; Chisaka and Capecchi 1991; Lufkin et al. 1991, 1992; Jegalian and De Robertis 1992; Le Mouellic et al. 1992; McLain et al. 1992; Pollock et al. 1992; Ramírez-Solis et al. 1993), supporting the role of hox genes in the specification of structures along the anteroposterior axis of the developing embryo (for review, see Deschamps and Meijlink 1992, McGinnis and Krumlauf 1992). The effects of some hox mutations, however, are complex and difficult to identify as posterior or anterior transformation (Chisaka et al. 1992). Also in the bmi-1 - / - mice it is unclear whether the broadening and the splitting of the atlas $(\mathrm{C} 1)$ or the axis $(\mathrm{C} 2)$ is true posterior transformation. However, a similar alteration is observed in hoxb-7 transgenic mice (McLain et al. 1992; for new nomenclature, see Scott 1992), which simultaneously display posterior transformation of C7 to T1. Possibly, partial redundancy, because of overlapping expression of paralogs from the different hox clusters in the mouse, might obscure clear transformation.

hox mutant mice display their transforming phenotype in general at a restricted region of the vertebral column. In bmi-1 - / - mice, however, we observe transformation along the complete anteroposterior axis in most cases. In that respect, $b m i-1-/-$ mice resemble more retinoic acid (RA)-treated mice. In a detailed study, Kessel and Gruss (1991) detected posterior transformation of vertebrae along the length of the vertebral column after exposure of mice to RA on day 7 of gestation: Interestingly, both vertebra identity and expression of several hox genes were affected. These data imply that in the bmi-1 - / - mice as well, the expression boundaries of several hox genes may have shifted to a more anterior position, possibly as an indirect effect of changes in RAmediated pathways. Although (in)direct regulation of hox genes by Bmi-1 remains to be established, the implication that Bmi-1 exerts its effect on at least a number of hox genes is in line with the way PSC, a member of the Pc-G of genes, is thought to function in Drosophila. Different members of the Pc-G are believed to form a large protein complex that facilitates or regulates the formation of condensed chromatin along specific regions of the chromosome, thereby causing permanent and heritable repression of homeotic genes (for review, see Paro 1990). Analogously, Bmi-1 could be one of the proteins of such a complex in the mouse, keeping genes of one or more of the hox clusters in a repressed heterochromatin state. A logical extension of this work should involve a detailed analysis of hox gene expression both during embryonic development as well as in the different hematopoietic lineages in which hox gene function has been implied (for review, see Lawrence and Largman 1992).

\section{Material and methods}

\section{Construction of targeting vectors}

A $129 /$ Ola genomic phage library was screened with a bmi-1 cDNA probe 13.1 (van Lohuizen et al. 1991a), and two overlapping $\lambda$ clones were obtained. A 15.2-kb BamHI-NotI fragment was subcloned in the pGEM4 vector (Promega), and subsequently a $2.5-\mathrm{kb}$ BamHI-KpnI fragment spanning exons 2-8 was replaced by either a 1.7-kb PGK-Hyg BamHI-BglII fragment /te Riele et al. 1990) or a $1.0-\mathrm{kb}$ pMCI-Neo BamHI fragment (te Riele et al. 1992). The targeting constructs were electroporated 
as a Sall fragment, separated from the vector sequences by gel electrophoresis.

\section{Propagation of the ES cells, targeting, and DNA analysis}

129/Ola-derived E14 ES cells (Hooper et al. 1987) were cultured in BRL-conditioned medium as described (Smith and Hooper 1987). Cells $\left(1.2 \times 10^{8}\right)$ were mixed with $90 \mu$ of either targeting construct in a volume of $600 \mu \mathrm{l}$ of PBS and electroporated with the Bio-Rad Gene Pulser $(0.8 \mathrm{kV}, 3 \mu \mathrm{F}$; electrode distance, 0.4 $\mathrm{cm})$. Cells were reseeded on $10-\mathrm{cm}$ tissue culture dishes at a density of $1.4 \times 10^{7}$ cells per dish. Drug selection $(200 \mu \mathrm{g} / \mathrm{ml}$ of G418 or $150 \mu \mathrm{g} / \mathrm{ml}$ of hygromycin) was started after $24 \mathrm{hr}$, and after 8 days resistant colonies were randomly picked and expanded. Clones were grown to confluency in 1 well of a 12-well dish; thereafter one-third of the cells was frozen in $10 \%$ DMSO in liquid nitrogen while the remainder of the cells was used to isolate genomic DNA for Southern blot analysis.

\section{Histological and anatomical analysis}

Tissues were isolated from mice and directly fixed in EAF [ $4 \%$ (vol $/ \mathrm{vol}$ ) formol, $40 \%$ (vol/vol) ethanol, $0.43 \%$ (wt/vol) $\mathrm{NaCl}$ and $5 \%$ (vol/vol) acetic acid) for $24 \mathrm{hr}$. Bone-containing tissues were decalcified in formic acid for $\sim 1$ week. Fixed and dehydrated tissues were embedded in Histowax and cut at $5-\mu \mathrm{m}$ sections and stained with hematoxylin and eosin stain. GFAP immunohistochemistry was performed with an polyclonal antiGFAP antibody (Chemicon, El Segundo, CA) and the avidinbiotin immunoperoxidase method ( $\mathrm{Hsu}$ et al. 1981) on $4 \%$ paraformaldehyde-fixed cryosections. In situ hybridization experiments were performed as described elsewhere (Vogels et al. 1990). The bmi-1 ${ }^{35} \mathrm{~S}$-labeled antisense RNA probe was transcribed by T7 RNA polymerase from a 803 -bp HpaII-BamHI cDNA fragment and partially hydrolyzed to an average length of 100 nucleotides. Skeletal whole mounts of newborn mice were performed on completely eviscerated animals with the skin removed. The livers were used for DNA isolation and genotype analysis by Southern blot hybridization. Corpses were fixed in $96 \%$ ethanol for 5 days and transferred to acetone for 2 days. Staining was performed in $0.005 \%$ alizarin red S, $0.015 \%$ alcian blue $8 \mathrm{GS}$ in $5 \%$ acetic acid, $5 \% \mathrm{H}_{2} \mathrm{O}$, and $90 \%$ ethanol for 3 days at $37^{\circ} \mathrm{C}$. Samples were washed in $\mathrm{H}_{2} \mathrm{O}$ and cleared for 2 days in $1 \% \mathrm{KOH}$ followed by clearing steps in $0.8 \% \mathrm{KOH}$ and $20 \%$ glycerol, in $0.5 \% \mathrm{KOH}$ and $50 \%$ glycerol, and in $0.2 \%$ $\mathrm{KOH}$ and $80 \%$ glycerol for at least 1 week each. Cleared skeletons were stored in $100 \%$ glycerol.

\section{Nucleated cell count determinations}

Whole blood was isolated in heparin-coated tubes, thymus and spleen were dissected from the mice, and single-cell suspensions were prepared in RPMI medium by use of open filter chambers to disrupt the tissue. Bone marrow cells were flushed from femurs and/or tibia with Fishers or RPMI medium. Nucleated cell count determination and blood cell scans were performed with an automated cell counter (Sysmex Toa F800).

\section{Flow cytometric analysis}

Cells $\left(3 \times 10^{5}\right)$ were incubated in 96-well plates for 30-45 min at $4{ }^{\circ} \mathrm{C}$ in $20 \mu \mathrm{l}$ of $\mathrm{PBS}^{2+}$ (phosphate-buffered saline with $1 \%$ BSA and $0.1 \%$ sodium azide) and saturating amounts of monoclonal antibody. Cells were washed two times with $\mathrm{PBS}^{2+}$ and incubated with streptavidin-phycoerytrin for biotinylated antibodies or mouse-anti-rat- $\kappa$-fluorescein for unconjugated antibodies. The cells were analyzed on a FACScan (Becton Dickinson).
The following antibodies were used: CD45R/B220 (6B2), CD3 (145-2C11), CD4 (RM4-5), CD8 (53-6.7), TCR $\alpha \beta$ (H57-597), Gr-1 (RB6-8C5), CD43 (S7), IL-2R (7D4) and mouse-anti-rat $\kappa$ light chain (MRK-1), all from Pharmingen (San Diego, CA). Heat stable antigen (30F1) was kindly provided by $\mathrm{K}$. Rajewski (University of Cologne, Germany). Mac-1 (M 1/70-15) was from Trowbridge and Omary (1981), and sIg/goat anti-mouse immunoglobulin was from Tago (Burlingame, CA).

\section{Tissue culture}

Colony assays were performed as described (Domen et al. 1993). Briefly, $5 \times 10^{4}$ bone marrow cells were plated in $3.5-\mathrm{cm}$ dishes in $1 \mathrm{ml}$ of medium containing $0.25 \%$ agar. Cells were incubated in Fisher's medium with $20 \%$ horse serum (GIBCO) in the presence of $20 \%$ L-cell-conditioned medium (containing M-CSF) or $20 \%$ WEHI-conditioned medium (containing IL-3) or in RPMI1640 medium (Flow) with $20 \%$ fetal calf serum (GIBCO), $5 \times 10^{-5} \mathrm{M} \beta$-mercaptoethanol and either $10 \mathrm{ng} / \mathrm{ml}$ of recombinant IL-7 (gift from Amgen Biologicals, Thousand Oaks, CA), 10 $\mathrm{ng} / \mathrm{ml}$ of recombinant IL-7 $+35 \mathrm{ng} / \mathrm{ml}$ of SF $\left(\mathrm{rrSCF}^{164}\right.$, gift from Amgen), or $30 \mu \mathrm{g} / \mathrm{ml}$ of LPS (Difco, Detroit, MI). Plates were incubated in a fully humidified incubator with $5 \% \mathrm{CO}_{2}$ for 8 days and colonies were counted. Every incubation was performed in triplicate. For liquid cultures, $1 \times 10^{6}$ bone marrow cells were incubated in $5 \mathrm{mls}$ of medium (RPMI 1640 plus $5 \%$ fetal calf serum, $5 \times 10^{5} \mathrm{M} \beta$-mercaptoethanol, penicillin, and streptomycin) and $10 \% 3 \mathrm{~T} 3-\mathrm{IL}-7$ conditioned medium with or without $60 \mathrm{ng} / \mathrm{ml}$ of $\mathrm{SF}\left(\mathrm{rrSCF}^{164}\right)$. The cells were incubated for 8-10 days, and samples were counted every other day.

\section{Proliferation assay}

Splenocytes were seeded at various densities in 96-well plates (U-bottom) in $100 \mu \mathrm{l}$ of complete Iscove's medium, supplemented with $2.5 \mu \mathrm{g} / \mathrm{ml}$ of ConA or $30 \mu \mathrm{g} / \mathrm{ml}$ of LPS. After $24 \mathrm{hr}$ of incubation at $37^{\circ} \mathrm{C},\left[{ }^{3} \mathrm{H}\right]$ thymidine was added to a final concentration of $4 \mu \mathrm{Ci} / \mathrm{ml}$. The cultures were incubated for an additional $4 \mathrm{hr}$ at $37^{\circ} \mathrm{C}$. The cells were collected on filters, washed, and $\left[{ }^{3} \mathrm{H}\right]$ thymidine incorporation was determined by scintillation counting.

\section{Acknowledgements}

We thank Joost Verhagen for assistance with the neurological analysis, Antje Brouwer and Ronald Vogels for their instructions and help with the in situ hybridization analysis, Eric Noteboom for assistance with the FACS analysis, K. Zsebo (Amgen, Thousand Oaks, CA) for a gift of Escherichia coli-derived rat $\mathrm{SCF}^{164}$, and Nel Bosnie, Tania Maidment, Auke Zwerver, and Loes Rijswijk for their help with handling and care of the mice. We thank $M$. Alkema for critically reading the manuscript. This work was supported by the Netherlands Organization for Scientific Research (NWO) (N.v.d.L; E.R.-M.) and by the Dutch Cancer Society (KWF) (K.L; M.v.R; H.teR.).

The publication costs of this article were defrayed in part by payment of page charges. This article must therefore be hereby marked "advertisement" in accordance with 18 USC section 1734 solely to indicate this fact.

\section{References}

Adler, P.N., J. Charlton, and B. Brunk. 1989. Genetic interactions of the Suppressor two of zeste region genes. Dev. Genet. 10: 249-260.

Adler, P.N., E.C. Martin, J. Charlton, and K. Jones. 1991. Phe- 
notypic consequences and genetic interaction of a null mutant in the Drosophila Posterior Sex Combs gene. Dev. Genet. 12: 349-361.

Bosma, G.C., M. Fried, R.P. Custer, A. Carroll, D.M. Gibson, and M.J. Bosma. 1988. Evidence of functional lymphocytes in some (leaky) scid mice. J. Exp. Med. 167: 1016-1033.

Brunk, B.P., E.C. Martin, and P.N. Adler. 1991. Drosophila genes Posterior Sex Combs and Suppressor two of zeste encode proteins with homology to the murine bmi-1 oncogene. Nature 353: 351-353.

Chisaka, O. and M.R. Capecchi. 1991. Regionally restricted developmental defects resulting from targeted disruption of the mouse homeobox gene Hox1.5. Nature 350: 473-479.

Chisaka, O., T.S. Musci, and M.R. Capecchi. 1992. Developmental defects of the ear, cranial nerves and hindbrain resulting from targeted disruption of the mouse homeobox gene Hox-1.6. Nature 355: 516-520.

Cumano, A., C.J. Paige, N.N. Iscove, and G. Brady. 1992. Bipotential precursors of $B$ cells and macrophages in murine fetal liver. Nature 356: 612-615.

Deschamps, J. and F. Meijlink. 1992. Mammalian homeobox genes in normal development and neoplasia. Crit. Rev. Oncogenesis 3: 117-173.

Domen, J., N.M.T. van der Lugt, D. Acton, P.W. Laird, K. Linders, and A. Berns. 1993. Pim-1 levels determine the size of early B lymphoid compartments in bone marrow. J. Exp. Med. 178: 1665-1673.

Dung, H.C. 1975. Growth retardation, high mortality and low reproductivity of neurological mutant mice. Anat. Rec. 181: 347-348.

-. . 1981. Lethargic mice. In Immunological defects in laboratory animals (ed. M.E. Gershwin and B. Merchant) vol. 2, pp.17-37. Plenum Press, New York.

Gipon, L.P., P. Schotman, F.G.I. Jennekens, and W.H. Gispen. 1977. Polyneuropathies and CNS protein metabolism. I. Description of the acrylamide syndrome in rats. Neuropathol. Appl. Neurobiol. 3: 115-123.

Goebl, M.G. 1992. The bmi-1 and mel-18 gene products define a new family of DNA-binding proteins involved in cell proliferation and tumorigenesis. Cell 66: 623.

Grabstein, K.H., T.J. Waldschmidt, F.D. Finkelman, B.W. Hess, A.R. Alpert, N.E. Boiani, A.E. Namen, and P.J. Morrissey. 1993. Inhibition of murine $B$ and $T$ lymphopoiesis in vivo by an anti-interleukin 7 monoclonal antibody. J. Exp. Med. 178: 257-264.

Hardy, R.R., C.E. Carmack, S.A. Shinton, J.D. Kemp, and K. Hayakawa. 1991. Resolution and characterization of pro-B and pre-pro-B cell stages in normal mouse bone marrow. $J$. Exp. Med. 173: 1213-1225.

Haupt, Y., G. Barri, and J.M. Adams. 1992. Nucleotide sequence of bup, an upstream gene in the bmi-1 proviral insertion locus. Mol. Biol. Rep. 17: 17-20.

Haupt, Y., W.S. Alexander, G. Barri, S.P. Klinken, and J.M. Adams. 1991. Novel zinc finger gene implicated as myc collaborator by retrovirally accelerated lymphomagenesis in $\mathrm{E} \mu$ myc transgenic mice. Cell 65: 753-763.

Hooper, M., K. Hardy, A. Handyside, S. Hunter, and M. Monk. 1987. HPRT-deficient (Lesch-Nyhan) mouse embryos derived from germ line colonization by cultured cells. Nature 326: 292-295.

Hsu, S.M., L. Raine, and H. Fanger. 1981. The use of avidinbiotin peroxidase complex $(\mathrm{ABC})$ in immunoperoxidase techniques: A comparison between $\mathrm{ABC}$ and unlabeled antibody (PAP) procedures. I. Histochem. Cytochem. 29: 577580 .

Jegalian, B.G. and E.M. De Robertis. 1992. Homeotic transfor- mations in the mouse induced by overexpression of a human Hox3.3 transgene. Cell 71: 901-910.

Jürgens, G. 1985. A group of genes controlling the spatial expression of the bithorax complex in Drosophila. Nature 316: 153-155.

Kaplan, M.L. and S.D. Murphy. 1972. Effect of acrylamide on Rotarod performance and sciatic nerve $\beta$-glucuronidase activity of rats. Toxicol. Appl. Pharmacol. 22: 259-268.

Kessel, M. and P. Gruss. 1991. Homeotic transformation of murine vertebrae and concomitant alteration of hox codes induced by retinoic acid. Cell 67: 89-104.

Kessel, M., R. Balling, and P. Gruss. 1990. Variations of cervical vertebrae after expression of a Hox1.1 transgene in mice. Cell 61: 301-308.

Kincade, P.W., G. Lee, C.E. Pietrangeli, S. Hayashi, and J.M. Gimble. 1989. Cells and molecules that regulate B lymphopoiesis in bone marrow. Annu. Rev. Immunol. 7: 111143.

Lawrence, H.J. and C. Largman. 1992. Homeobox genes in normal hematopoiesis and leukemia. Blood 80: 2445-2453.

Lee, G., A.E. Namen, S. Gillis, L.R. Ellingsworth, and P.W. Kincade. 1989. Normal B-cell precursors responsive to recombinant murine IL-7 and inhibition of IL-7 activity by transforming growth factor- $\beta$. I. Immunol. 142: 3875-3883.

Le Mouellic, H., Y. Lallemand, and P. Brulet. 1992. Homeosis in the mouse induced by a null mutation in the Hox3.1 gene. Cell 69: 251-264.

Lewis, E.B. 1978. A gene complex controlling segmentation in Drosophila. Nature 276: 565-570.

Lothman, E.W., E.H. Betram, and J.L. Stringer. 1991. Functional anatomy of hippocampal seizures. Prog. Neurobiol. 37: 182.

Lufkin, T., A. Dierich, M. LeMeur, M. Mark, and P. Chambon. 1991. Disruption of the Hox1.6 homeobox gene results in defects in a region corresponding to its rostral domain of expression. Cell 66: 1105-1119.

Lufkin, T., M. Mark, C. Hart, P. Dollé, M. LeMeur, and P. Chambon. 1992. Homeotic transformation of the occipital bones of the skull by ectopic expression of a homeobox gene in transgenic mice. Nature 359: 835-841.

Lyon, M.F. and A.G. Searle, eds. 1989. Genetic variants and strains of the laboratory mouse, 2nd ed, Oxford University Press, Oxford, England.

Martin, E.C. and P.N. Adler. 1993. The Polycomb group gene Posterior Sex Combs encodes a chromosomal protein. Development 117: 641-655.

McGinnis, W. and R. Krumlauf. 1992. Homeobox genes and axial patterning. Cell 68: 283-302.

McLain, K., C. Schreiner, K.Y. Yager, J.L. Stock, and S.S. Potter. 1992. Ectopic expression of Hox 2.3 induces craniofacial and skeletal malformations in transgenic mice. Mech. Dev. 39: 3-16.

McNiece, K., K.E. Langley, and K.M. Zsebo. 1991. The role of recombinant stem cell factor in early B cell development. $J$. Immunol. 146: 3785-3790.

Paro, R. 1990. Imprinting a determined state into the chromatin of Drosophila. Trends Genet. 6: 416-421.

Pollock, R.A., G. Jay, and C.J. Bieberich. 1992. Altering the boundaries of Hox3.1 expression: Evidence for antipodal gene regulation. Cell 71: 911-923.

Ramírez-Solis, R., H. Zheng, J. Whiting, R. Krumlauf, and A. Bradley. 1993. Hoxb-4 (Hox2.6) mutant mice show homeotic transformation of a cervical vertebra and defects in the closure of the sternal rudiments. Cell 73: 279-294.

Scott, M.P. 1992. Vertebrate homeobox gene nomenclature. Cell 71: 551-553. 
Smith, A.G. and M.L. Hooper. 1987. Buffalo rat liver cells produce a diffusible activity which inhibits the differentiation of murine embryonal carcinoma and embryonic stem cells. Dev. Biol. 121: 1-9.

Stanley, E.R., L.J. Guilbert, R.J. Tushinski, and S.H. Bartelmez. 1983. CSF-1 mononuclear phagocyte lineage-specific hematopoietic growth factor. I. Cell. Biochem. 21: 151-159.

Suda, T. and A. Zlotnik. 1991. IL-7 maintains the T cell precursor potential of $\mathrm{CD} 4^{-} / \mathrm{CD}^{-} / \mathrm{CD}^{-}$thymocytes. J. Immunol. 146: 3068-3073.

Suda, T., S. Okada, J. Suda, Y. Miura, M. Ito, T. Sudo, S-I. Hayashi, N-I. Nishikawa, and H. Nakauchi. 1989. A stimulatory effect of recombinant interleukin-7 on B-cell colony formation and an inhibitory effect of interleukin-1 $\alpha$. Blood 74: 1936-1941.

Tagawa, M., T. Sakamoto, K. Shigemoto, H. Matsubaru, Y. Tamura, T. Ito, I. Nakamura, A. Okitsu, K. Imai, and M. Taniguchi. 1990. Expression of a novel DNA-binding protein with zinc finger structure in various tumor cells. $J$. Biol. Chem. 265: 20021-20026.

Tavassoli, M., A. Maniatis, and W.H. Crosby. 1974. Induction of sustained hemopoiesis in fatty marrow. Blood 43: 33-38.

te Riele, H., E. Robanus Maandag, A. Clarke, M. Hooper, and A. Bems. 1990. Consecutive inactivation of both alleles of the pim-1 proto-oncogene by homologous recombination in embryonic stem cells. Nature 348: 649-651.

te Riele, H., E. Robanus Maandag, and A. Berns. 1992. Highly efficient gene targeting in embryonic stem cells through homologous recombination with isogenic DNA constructs. Proc. Natl. Acad. Sci. 89: 5128-5132.

Trowbridge, I.S. and M.B. Omary. 1981. Molecular complexity of leucocyte surface glycoproteins related to the macrophage differentiation antigen mac-1. I. Exp. Med. 154: 1517-1524.

van Lohuizen, M., S. Verbeek, B. Scheijen, E. Wientjens, H. van der Gulden, and A. Berns. 1991a. Identification of cooperating oncogenes in $\mathrm{E} \mu-m y c$ transgenic mice by provirus tagging. Cell 65: 737-752.

van Lohuizen, M., M. Frasch, E. Wientjens, and A. Berns. 1991b. Sequence similarity between the mammalian bmi-1 protooncogene and the Drosophila regulatory genes Psc and Su(z)2. Nature 353: 353-355.

Vogels, R., W. de Graaff, and J. Deschamps. 1990. Expression of the murine homeobox-containing gene hox-2.3 suggests multiple time-dependent and tissue-specific roles during development. Development 110: 1159-1168.

Wang, Z., C. Ovitt, A.E. Grigoriadis, U. Möhle-Steinlein, U. Rüther, and E.F. Wagner. 1992. Bone and haematopoietic defects in mice lacking c-fos. Nature 360: 741-745.

Wu, C.T., R.S. Jones, P.F. Lasko, and W.M. Gelbart. 1989. Homeosis and the interaction of zeste and white in Drosophila. Mol. Gen. Genet. 218: 559-564.

Zink, B., Y. Engström, W.J. Gehring, and R. Paro. 1991. Direct interaction of the Polycomb protein with Antennapedia regulatory sequences in polytene chromosomes of Drosophila melanogaster. EMBO J. 10: 153-162. 


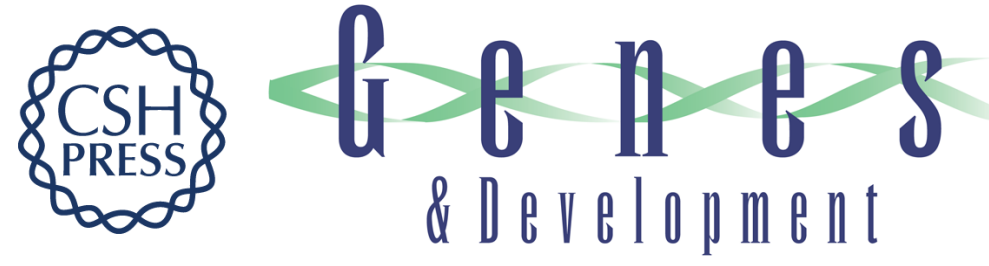

\section{Posterior transformation, neurological abnormalities, and severe hematopoietic defects in mice with a targeted deletion of the bmi-1 proto-oncogene.}

$\mathrm{N}$ M van der Lugt, J Domen, $\mathrm{K}$ Linders, et al.

Genes Dev. 1994, 8:

Access the most recent version at doi:10.1101/gad.8.7.757

References This article cites 54 articles, 15 of which can be accessed free at: http://genesdev.cshlp.org/content/8/7/757.full.html\#ref-list-1

License

Email Alerting Service

Receive free email alerts when new articles cite this article - sign up in the box at the top right corner of the article or click here.

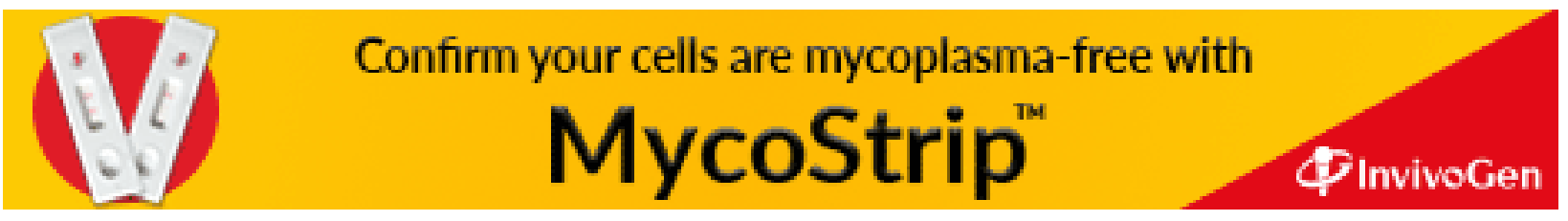

